Eugenia M. Chernina*

\title{
The Role of Migration Experience in Migrants' Destination Choice
}

\begin{abstract}
In this article, we employ a panel household survey from Tajikistan to study labor migrants' location choices in Russia. We find that labor migrants from Tajikistan consider a wide variety of economic, demographic, and geographical characteristics of Russian regions when making location choices. We also find that experienced migrants are less responsive to current regional characteristics that might suggest path dependence in destination choices by experienced migrants.
\end{abstract}

\begin{tabular}{|c|c|}
\hline Current version: & October 22, 2019 \\
\hline Keywords: & $\begin{array}{l}\text { Russia; Tajikistan; international migration; labor migration; } \\
\text { location choice }\end{array}$ \\
\hline JEL codes: & F22, J61, R23 \\
\hline Corresponding author: & $\begin{array}{l}\text { Eugenia M. Chernina } \\
\text { echernina@hse.ru }\end{array}$ \\
\hline
\end{tabular}

* Centre for Labour Market Studies (CLMS) at National Research University Higher School of Economics, 4/2 Slavyanskaya Ploshchad, Moscow 103074, Russia. E-mail: echernina@hse.ru. Tel.: +79167379286 


\section{Introduction}

It has long been noticed that migrants' distribution over the receiving country does not replicate the one of natives (Chiswick and Miller, 2004). Migrants often concentrate in particular locations. Understanding the reasons of observed settlement patterns is important for many reasons. The first reason is because of the impact that migrants might have on the natives' labor market outcomes (Longhi et al., 2008; Kerr and Kerr, 2011), settlement decisions (Borjas, 2006; Mocetti and Porello, 2010), and other outcomes. The second reason is that migrant success in the receiving country considerably depends on a settlement decision (Damm, 2009; Edin et al., 2004; Chiswick and Miller, 2005).

The economic literature on migrants' location choices points to several important factors determining migration destinations. Among them, the labor market characteristics of the receiving regions and co-ethnics concentration have been extensively explored. Regional economic characteristics represent opportunities in the labor market, while concentration of co-ethnics represents available migrant networks. Migrants rely on networks that provide information and direct assistance with job search, accommodation, legal issues, and so on. Networks also provide ethnic goods such as food, clothing, social organizations, religious services, and so on. Thus, current migrants' choices depend on the migration decisions of their predecessors.

Research results about the importance of the two aforementioned factors vary considerably depending on migrant characteristics and data source. For example, in the case of the USA, Bartel (1989) and Kaushal and Kaestner (2010) showed, using the census data, that the level of immigrants' concentration is important while economic factors have little or no effect. Immigrant concentration was a significant factor in many other studies and survives even control for location fixed effects (Jaeger, 2007). Other studies (Zavodny, 1999; Jaeger, 2000; Jaeger, 2007), employing admission data from the Immigration and Naturalization Service, show the considerable role of regional economic factors in attracting migrants. The relative importance of the factors depends on various migrant's personal characteristics: education, age, gender, marital status, previous occupation, country of origin, visa type, and legal status (Scott et al., 2005; Pena, 2009; Jaeger, 2000; Jaeger, 2007; Bartel, 1989; Kaushal and Kaestner, 2010). In general, economic factors turn out to be more important for migrants who are employment-based, better educated, more qualified and legal, while the effect of ethnic concentration is higher for the low-skilled.

Most of the discussed papers study the location choices of the long-term or permanent and predominantly legal migrants, while location choices of the short-term and circular migrants seem to be understudied (a notable exception is a series of papers by Bauer et al. $(2005,2007$, 2009). In the case of repeated migration episodes, personal migration history plays an important role. Path dependence in location choice arises because migrants have higher expected returns and lower costs at familiar destinations. First, there are unobserved characteristics of destinations that do not vary with time (e.g., migrant's preexisting connections to people residing in the region). Second, migrants build new connections upon arrival both with the existing ethnic network, local population, and employers. They make other investments in a receiving region-specific human capital (e.g., knowledge of local laws, rules, and local labor market). With accumulation of experience in the receiving country's labor market, migrants can rely on their own knowledge and connections to find employment. Thus, experienced migrants 
become attached to their previous destinations and may not be sensitive to the current situation in the regions.

In this article, the author explores the location choices of temporary labor migrants in Russia, both legal and illegal, using individual data from a sending country - Tajikistan. The article has two main aims. First, to find out what regional characteristics are important for migrants' location choices. Second, to find out how migration experience affects the determinants of location decision. To the author's knowledge, this is the first article that empirically investigates the destinations of temporary migrants in Russia using micro-level data and one of a few that accounts for migration experience while exploring the factors of location choice.

The data employed in this study are the 2007 and $2009^{1}$ waves of the Tajikistan Living Standard Survey (TLSS) and its extension, the Tajikistan Household Panel Survey (THPS) in 2011. ${ }^{2}$ The author finds that both regional economic characteristics and the presence of co-ethnics determine labor migrants' choices. Apart from traditional factors, the author accounts for the differences in migration policy across Russian regions. In the studied period of 2007-2011, there were migration quotas defined at the regional level. Introduced to fight illegal migration, these quotas had mixed success in shaping migration streams. For the majority of regional characteristics, the author finds that the effects on the probability of migrants choosing a region declines with migration experience. So, current regional characteristics are much less relevant for the experienced migrants.

The rest of the article is organized as follows: after describing the patterns of Tajik migration to Russia in Section 2, the author discusses the theoretical foundations in Section 3. The author presents the data description and descriptive statistics in Section 4. Finally, the author presents the empirical results and their robustness in Section 5.

\section{Tajikistan - Russia migration facts and 2008-2009 financial crisis}

Tajikistan is a mountainous country with a predominantly rural and fast-growing population. Over the past quarter of a century, Tajikistan has had the lowest per capita GDP among the Commonwealth of Independent States (CIS) countries, and the poverty level (at the \$3.1 2011 PPP) was measured as 33\% in 2007 and 23.4\% in 2009. ${ }^{3}$ Tajikistan's soil is not well-suited for agriculture, although Tajikistan is a major exporter of cotton. Its industrial capacity is represented by a large aluminum plant and number of large and medium-size hydroelectric power stations. Between 1992 and 1997, Tajikistan went through a Civil War that caused serious damage to the country's economy and long and varied effects on the accumulation of human capital and the labor market behavior of the Tajik population (Shemyakina, 2011a; Shemyakina, 2011b).

1 State Statistical Agency of Tajikistan (2007) and State Statistical Agency of Tajikistan (2009) - the two rounds of survey were conducted by the State Statistics Committee of the Republic of Tajikistan with the participation of the World Bank and UNICEF in October-November 2007 and 2009, see http://microdata.worldbank.org/index.php/catalog/72 and http://microdata.worldbank.org/index.php/catalog/73.

2 The survey Tajikistan Household Panel Survey (2011) was initiated by The Leibniz Institute for East and Southeast European Studies (Germany) and conducted jointly with the Research Center "Shark" in Dushanbe, see http://www. lambda.ios-regensburg.de/doi/thps_2011.html.

3 Here and after, Tajikistan's macro statistics is taken from the Word Bank (2018). 
The collapse of the Soviet Union and the civil war caused a surge in migration. Internal migration was mainly caused by the civil war and external migration, in the first years of independence, occurred mainly for ethnic reasons, while in the following years economic reasons prevailed. Migration was a response to a difficult economic situation in the country and was a widespread survival strategy for Tajik households. Tajikistan's economy is highly dependent on remittances: the ratio of remittances to GDP reached almost $50 \%$ and was the world's highest in 2008 (World Bank, 2007, 2008, 2009a).

Estimates of the number of workers sent abroad vary. According to the household surveys, the stock of Tajik citizens who worked abroad was 300,000 in 2007 and 560,000 in 2009 (Kumo, 2012). Choudinovskikh and Denissenko (2013) give an estimate of 430,000 that is based on a Labor force survey 2008. About 95\% of Tajik migrants go to Russia (according to the TLSS data). The number of registered labor migrants from Tajikistan in Russia was 250,000 in 2007, 360,000 in 2009 , and 330,000 in 2011 , constituting $15-16 \%$ of the registered labor migration, making Tajikistan the second largest among all sending countries.

Russia started attracting labor migrants from the post-Soviet space in the period of rapid economic growth of the 2000s. Officially registered foreign workers made up $2.5-3.5 \%$ of the Russian labor force in 2007-2013 (Russian State Statistical Committee, 2011). In some industries, this share was much higher. For example, in construction where almost $40 \%$ of registered foreign workers were employed in 2009-2010; their share was about 16\%. Trade was the second most important area of employment, attracting 18\% and $17 \%$ of foreign workers in 2009 and 2010, respectively. Migrants were predominantly male and low-skilled. As we will see later, migrants from Tajikistan share this typical profile.

Since 2007, a policy of regional migration quotas was introduced. The quotas were the regional limits for the number of work permits that could be issued for foreign low-skilled workers. When first introduced by the law in 2007, the quotas were not binding. The number of permits was 6 million for the whole country. The regional distribution of quotas was first defined by central authorities, taking into account the socioeconomic situation in the regions. Starting from 2009, the quotas were defined in accordance with employers' applications for hiring migrant workers that should have been submitted during the preceding year.

The period of the 2008-2009 world economic crisis enters our dataset, so it is worth discussing what impact it had on the sending and receiving countries. Russia experienced one of the world's largest shocks during 2008-2009 and the fall of its GDP in 2009 was as high as $7.8 \%$ (Russian State Statistical Committee, 2019). Industries that suffered the most were manufacturing (-13.9\% in 2009), construction (-16.4\% in 2009), and retail trade ( $-8.3 \%$ in 2009$)$ (World Bank, 2009b), the last two being the top employers of migrant labor. Migration policy immediately responded to the crisis with reductions in migration quotas for 2009 that were cut by the Presidential decree, by 50\% from the planned nearly 4 million. Complications were also introduced to the application procedures for the firms that wanted to hire migrant workers. As a result, the number of issued work permits fell in 2009 by $30 \%$ compared to 2008 . Migrants also faced more abuse by employers and a higher risk of deportation (Marat, 2009).

The crisis heavily hit the Tajik economy through a slump in the prices of its exports (cotton and aluminum) and the drying of the migrant remittances stream. These two factors resulted in a reduction of GDP growth rates from $21 \%$ in 2008 to $4 \%$ in 2009. Still, the crisis only spurred the participation of Tajik households in labor migration. Kröger and Meier (2011) show 
that members of households affected by the slump in export prices were more likely to send household members to work abroad. Additional household members were sent to support the stream of remittances (Marat, 2009; Danzer and Ivaschenko, 2010). Danzer and Dietz (2018) show that, on average, the duration of migration and net income from migration increased during the financial crisis in spite of the shrinking average wages.

\section{Theoretical model and empirical estimation}

To explore the determinants of location decisions of Tajik migrants in Russia, the author employed a standard discrete choice model, which has been used in many previous studies (Bartel, 1989; Bauer et al., 2009; Jaeger, 2007). This approach, in the case of micro-level data, allows for the choice between a limited number of destinations to be modeled.

Let us assume that a potential migrant makes a location decision each period. When making this migration decision, a migrant compares costs and benefits of migration to each of the possible destinations and decides on the location with the highest net benefits. The benefits from migration are mostly related to the expected earnings in that particular destination. The costs of migration depend on many factors that include the direct costs of obtaining tickets, travel documents and passports, costs of settling up at the destination, and housing and registration costs.

Formally, let individual $i$ in period $t$ choose between $j=1, \ldots, N$ destinations that bring utility $U_{i j t}$. The probability of choosing destination $j$ is then:

$$
\operatorname{Pr}\left(\operatorname{Mig}_{i j t}\right)=\mathrm{P}\left(U_{i j t}=\max \left(U_{i 1 t}, U_{i 2 t}, \ldots, U_{i N t}\right)\right)
$$

Utility of the individual $i$ from destination $j$ in period $t, U_{i j t}=f\left(G_{i j t}\right)$, is a function of the factors that contribute to the gain from migration $G_{i j t}$ :

$$
G_{i j t}=p_{i j t}{ }^{*} w_{i j t}-C_{i j t}
$$

where $p_{i j t}$ - probability of employment, $w_{i j t}$ - migrant's wage, and $C_{i j t}$ - migration costs. In turn, each of the factors $p_{i j t}, w_{i j t}$, and $C_{i j t}$ depends on four components. These are destination characteristics $Z_{j t-1}$ (such as labor market characteristics and co-ethnic concentration), migrant's personal characteristics $X_{i t}$ (age, gender, education, and migration experience), their interactions $X_{i t}{ }^{*} Z_{j t-1}$ and a random component $e_{i j t}$.

The author assumes a linear relation between the utility and the factors $X_{i t}, Z_{j t-1}$, and $e_{i j t}$ :

$$
U_{i j t}=\beta Z_{j t-1}+\gamma Z_{j t-1}{ }^{*} X_{i t}+\alpha X_{i t}+e_{i j t}
$$

Substituting Eq. (3) into Eq. (1) and assuming that returns to individual characteristics, $\alpha$, are the same at all destinations, we get:

$$
\operatorname{Pr}\left(M i g_{i j t}\right)=\mathrm{P}\left(\beta_{j t-1}+\gamma Z_{j t-1}{ }^{*} X_{i t}+e_{i j t}>\beta Z_{k t-1}+\gamma Z_{k t-1}{ }^{*} X_{i t}+e_{i k t}, k \neq j\right),
$$

Assuming that $e_{i j t}$ is an independent and identically distributed random variable with Weibull distribution Eq. (4) could be written as:

$$
\operatorname{Pr}\left(M i g_{i j t}\right)=\frac{\exp \left(\beta Z_{j t-1}+\gamma Z_{j t-1}{ }^{\star} X_{i t}\right)}{\sum_{j=1}^{N} \exp \left(\beta Z_{j t-1}+\gamma Z_{j t-1}^{*} X_{i t}\right)}
$$


Obtained expression is the conditional logistic regression model or McFadden choice model. Parameters $\beta$ and $\gamma$ are estimated by maximization of the likelihood function that is a sum of logs of Eq. (5) for all observations.

An important property of this model is the independence of irrelevant alternatives (IIA). It can be easily seen from Eq. (5). The property means that the relative probability of choosing two alternatives depends only on these alternatives' characteristics and does not depend on the choice set. This property allows for destinations that did not enter the sample to be ignored. Although, in the case of spatial choice, we might expect this assumption not to be fulfilled, as less distant alternatives can be expected to be closer substitutes for each other. As shown in (Cushing, 2007) and (Dahlberg and Eklöf, 2003), results of a conditional logit model in a migration context are sensitive to the IIA assumption with the problem of omitted variables. If a model is well-specified, results of the conditional logit model are comparable to mixed logit and multinomial probit models that relax the IIA assumption. An important way, at least partly, to account for a region's unobserved heterogeneity, is control for groups of regions that are similar (Schneider and Kubis, 2009). In the case of Russia, a common way to aggregate regions are geographic macro regions - federal districts. To partly eliminate the problem of the IIA assumption violation, controls for the federal districts will be included.

\section{Data and descriptive statistics}

The samples of TLSS and THPS are representative on the national, regional, and rural/urban levels. During the 2007 survey, 4,500 households and 32,000 individuals were interviewed between September and November. The 2009 wave of the survey was held in October and November using a random subsample, comprising 1,503 households and 7,000 individuals. In 2011, again 1,503 households were interviewed; the households that dropped out since 2009 were replaced by households that participated in the 2007 survey.

The household questionnaires include a migration section that provides information on each member's migration experience, with detailed information of the last trip. That information includes earnings, destination, legal status, and questions regarding how the trip was organized. The questions are answered by the migrants themselves if they are currently in the household or the household head if migrants are away.

The author defines the sample of all migrants who were in Russia in the survey year, who returned home in the survey year, or were abroad at the time of the survey. This allows to make the sample as close as possible to the definition of the stock of migrants in the destination country in a particular year. This leaves us with 1,125 individuals in 2007, 688 in 2009, and 849 in 2011.

As can be seen in Table 1, Tajik migrants are predominantly young males with a secondary general education from large rural households. In Russia, Tajik migrants occupy lowskilled jobs, often in the construction sector. Most often, Tajik migrants are engaged in circular and seasonal migration. The average stay of return migrants in all three rounds was 10 months.

To measure the migration experience, the author uses information from the return migrants about the number of years they were abroad (this information is available in 2009 and 2011). In addition, migrants absent in 2011 can be matched between the survey rounds to sum up their migration experience in 2010 and 2011 with their experience reported in 2009. 
Therefore, the experience measure is defined only for a subsample of migrants: 59\% of migrant sample in 2009 and $71 \%$ of migrant sample in 2011.

The average time spent abroad is 2.9 years with a range of $1-17$ years. Table 2 shows how migrant characteristics vary with migration experience. We see a clear trend of more females in the later migration cohorts. Also, migrants with less experience have a lower education level. Indeed, the trends we see are a combination of changes in selection into migration and selection out of migration. However, different socio-demographic profiles should be taken into account in the analysis.

The survey asked each migrant which town or city they had been living in, and also for those who were still officially a migrant, which city were they currently living in. The author assumes that in the case of return migrants, they report their last destination as they theoretically could change it during the trip (the model assumes that migrants may choose the location for each period). Although the survey question asked about the migrant destination city, the

Table 1 Migrant characteristics $(2007,2009,2011)$

\begin{tabular}{lccc}
\hline & Mean & St. Err. & $\begin{array}{c}\text { Number of } \\
\text { observations }\end{array}$ \\
\hline Urban household,\% & 23.9 & 0.8 & 2,662 \\
Age & 30.0 & 0.2 & 2,662 \\
Male, \% & 92.1 & 0.5 & 2,662 \\
Education & & & \\
Primary, \% & 11.4 & 0.6 & 2,657 \\
Secondary, \% & 62.7 & 0.9 & 2,657 \\
Specialized secondary, \% & 15.0 & 0.7 & 2,657 \\
Higher or doctoral, \% & 10.9 & 0.6 & 2,657 \\
Occupation in Russia & & & \\
Elementary occupations (ISCO* 9), \% & 17.2 & 0.7 & 2,662 \\
Stall and market salespersons (ISCO 523), \% & 4.5 & 0.4 & 2,662 \\
Building frame, building finishers and related traders & 30.2 & 0.9 & 2,662 \\
(ISCO 712, 713), \% & & & 2,082 \\
Speaks Russian, \% & 92.1 & 0.6 & 765 \\
Stay abroad, months (for return migrants) & 9.9 & 0.3 & \\
\hline
\end{tabular}

Note: *ISCO, International Standard Classification of Occupations.

Table 2 Migrant characteristics by years of migration experience

\begin{tabular}{|c|c|c|c|c|c|c|}
\hline & \multicolumn{2}{|c|}{$\begin{array}{l}\text { 1-2 years of } \\
\text { experience }\end{array}$} & \multicolumn{2}{|c|}{$\begin{array}{l}\text { 3-4 years of } \\
\text { experience }\end{array}$} & \multicolumn{2}{|c|}{$\begin{array}{l}>4 \text { years of } \\
\text { experience }\end{array}$} \\
\hline & Mean & St. Err. & Mean & St. Err. & Mean & St. Err. \\
\hline Male, \% & 91.4 & 1.1 & 94.0 & 1.4 & 99.2 & 0.8 \\
\hline \multicolumn{7}{|l|}{ Education } \\
\hline Primary, \% & 10.4 & 1.2 & 9.9 & 1.8 & 5.7 & 2.1 \\
\hline Secondary general, \% & 65.2 & 1.9 & 57.4 & 2.9 & 49.2 & 4.5 \\
\hline Specialized secondary, \% & 14.6 & 1.4 & 18.8 & 2.3 & 28.7 & 4.1 \\
\hline Higher or doctoral, \% & 9.8 & 1.2 & 13.8 & 2.1 & 16.4 & 3.4 \\
\hline Number of observations & 605 & & 282 & & 122 & \\
\hline
\end{tabular}


analysis will be carried out on a regional level. First, we cannot be sure whether a migrant actually stays in the city as opposed to just naming the largest city of the region. Second, regional-level statistics are more reliable in Russia.

Table 3 shows the top destinations for Tajik migrants (see the complete list of destinations in Table A1 in Appendix) captured by the TLSS-THPS household surveys. Migrants in the three rounds were distributed between at least ${ }^{4} 53$ cities in 41 regions of Russia (out of 83). The distribution of migrants between destinations is highly concentrated: Moscow attracts about $60 \%$ of all migrants, and this percentage was growing through the rounds, while the top 10 destinations attracted over $80 \%$. The concentration of migrants in Moscow has been growing in 2007-2011 by approximately 1 p.p. per year.

According to the aforementioned model, migrant destination choice is driven by the probability of employment, wages, and migration costs. These can be predicted with various regional characteristics $\left(Z_{j t-1}\right.$ in our model's notation). As discussed earlier, several groups of regional factors contribute to a migrant's expected utility from destinations, with labor market characteristics and networks being of particular importance. Regional unemployment, population size, population density, labor force sectoral structure, the size of the construction sector ${ }^{5}$ and, partly, migration quotas ${ }^{6}$ all contribute to predicting migrant employment probability (see sample averages in Table A2 in Appendix). The average regional wage ${ }^{7}$ is a proxy for differentials in migrant wages. As a robustness check, the author constructed an indicator which is a weighted average of mean wages in ISCO occupational groups, in which migrants work. This measure could be a better proxy for a migrant's expected wages. Indeed, local wages are not perfect proxies because regions differ in terms of the migrant position in the distribution

Table 3 Top migrant destinations and selected destination characteristics

\begin{tabular}{lccccccc}
\hline \multirow{2}{*}{ Region } & \multicolumn{2}{c}{$\begin{array}{c}\text { \% } \\
\text { migrants }\end{array}$} & $\begin{array}{c}\text { \% } \\
\text { migrants }\end{array}$ & $\begin{array}{c}\text { \% } \\
\text { migrants }\end{array}$ & $\begin{array}{c}\text { Population } \\
\text { size, } \\
\text { thousands }\end{array}$ & $\begin{array}{c}\text { Average } \\
\text { wage, RuR }\end{array}$ & $\begin{array}{c}\text { Unemployment } \\
\text { rate,\% }\end{array}$ \\
\cline { 2 - 8 } & Total & $\mathbf{2 0 0 7}$ & $\mathbf{2 0 0 9}$ & $\mathbf{2 0 1 1}$ & $\mathbf{2 0 0 9}$ & $\mathbf{2 0 0 8}$ & $\mathbf{2 0 0 8}$ \\
\hline Moscow & 60.23 & 57.79 & 60.75 & 63.31 & 10,563 & 30,552 & 0.9 \\
St Petersburg & 6.54 & 6.7 & 6.18 & 6.6 & 4,600 & 22,473 & 2.0 \\
Sverdlovskaya obl. & 5.82 & 6.39 & 5.91 & 4.92 & 4,394 & 17,527 & 4.8 \\
Tyumenskaya obl. & 2.19 & 1.56 & 3.23 & 2.24 & 3,430 & 33,877 & 6.5 \\
Irkutskaya obl. & 1.85 & 1.4 & 1.08 & 3.13 & 2,503 & 17,072 & 8.7 \\
Samarskaya obl. & 1.85 & 2.18 & 1.75 & 1.45 & 3,170 & 14,675 & 4.2 \\
Chelyabinskaya obl. & 1.75 & 1.71 & 1.34 & 2.13 & 3,509 & 14,829 & 4.4 \\
Novosibirskaya obl. & 1.23 & 1.32 & 1.48 & 0.89 & 2,650 & 15,714 & 7.3 \\
Krasnodarsky kray & 1.16 & 1.01 & 0.4 & 2.01 & 5,214 & 13,163 & 4.8 \\
Volgogradskaya obl. & 0.92 & 0.86 & 1.08 & 0.89 & 2,590 & 12,002 & 8.1 \\
\hline
\end{tabular}

4 For $9 \%$ of migrants, exact destination is unknown.

5 Regional statistics is taken from sources of the Russian State Statistical Committee (Russian State Statistical Committee 2018c; Russian State Statistical Committee, 2018d).

6 Information on migration quotas was taken from the orders issued by the Russian Ministry of Health and Social Development (2007, 2008a, 2008b, 2009, 2010).

7 Nominal wages are used as labor migrants send considerable part of their earnings as remittances, so they are expected to consider nominal earnings. 
of earnings. The gap between migrant and native wages is much higher in the capital compared to other regions (Denisenko and Chernina, 2017). Labor migrants were mainly concentrated in economic and industrial centers across the country. Moscow, which attracts the majority of migrants, stands out with a large population size, low unemployment, and high wages that can be compared only with the northern oil-extracting Tyumen region (Table 3).

Economic dynamics measures might affect migrant choices both through wage, employment, and migration costs. For example, adverse economic dynamics not only means an increase in current unemployment and a reduction in current wages and economic activity, but may also affect the migrant position through changes in attitudes toward migrants, and the willingness to employ them. On the one hand, during times of crisis, local populations become more hostile toward migrants, and there might be a higher risk of deportation. On the other hand, businesses might be more willing to replace their more expensive local workers with cheap migrant labor. Another consideration concerns the change in the construction sector output. The considerable change in the industry may create a deficit of local labor resources and make employers more likely to employ migrant labor. We do not see a considerable decline in the data (Table A2 in Appendix) because regional characteristics of the year preceding migration are used in the regressions.

Networks are another important factor that drives location decisions. Networks reduce costs of migration and improve employment prospects and wages (e.g., ethnic discrimination is absent when migrants are hired by more prosperous co-ethnics). There is no doubt that migrants rely on personal connections while making location decisions. For example, about $56 \%$ of return migrants in the 2009 TLSS report that connection with relatives, friends, or acquaintances is considered to be the main reason for choosing the destination country. About $16 \%$ report that the reason was a pre-arranged job, and nearly $20 \%$ report the reason as, they "have been there before". The question regarding the means of job search reveals why networks are so important: nearly $90 \%$ received information about job opportunities from friends, relatives, and neighbors in Tajikistan and abroad. Personal connections provide migrants with information about potential migration destinations and conditions and provide help in job searching and accommodation.

It is not easy to define who constitute migrant networks, and this question is discussed in extensive literature. Although migrant connections in the receiving country are not necessarily ethnic ones, often migrants rely on previous or current migrants who originate from the same country, region of the country, community or family. Davis et al. (2002) show that the closer the kinship bond, the more important the impact of connection on the migration decision. The importance of certain connections depends on many factors. Usually, better skilled immigrants have more ethnically varied connections. For example, Bauer et al. (2005) show that immigrants from Mexico with better English proficiency choose to migrate to United States locations with lower concentrations of immigrants of similar ethnicity and language. It should be also noted that network effects (positive externalities from previous migrants) should be distinguished from herd effects-a pure information effect that implies that migrants look at the recent decisions of their peers, assuming that the latter have more information than they do (Bauer et al. 2007).

How can we measure networks for migrants from Tajikistan? For the early years of mass migration from Tajikistan, Olimova and Bosc (2003) observe that the following 
connections were important for destination choices: Tajik community or ethnic Russians from Tajikistan, contacts dating back to the Soviet period between similar or partner enterprises, Soviet-era contacts established through organized recruitment. With time, we can expect Soviet contacts to become less important, while previously settled Tajiks should continue to provide support for temporary labor migrants. Moreover, new connections with the local population would be formed. Many previous studies have used a number or share of permanently settled co-ethnics, estimated from the census or register data, as a measure of the available network for newcomers (Bauer et al., 2007; Beine and Salomone, 2013; Beine et al., 2015).

Yearly data on the permanent Tajik population in Russia are based on the 2002 and 2010 population censuses and are projections assuming continuous change in the number of ethnic Tajiks residing in a region between the census years (Table A2 in Appendix). According to this data, the share of ethnic Tajiks in the Russian population ${ }^{8}$ is relatively small. The number of ethnic Tajiks was about 120,000 ( $0.08 \%$ of population $)^{9}$ in 2002 and 200,000 $(0.15 \% \text { of population })^{10}$ in 2010 , with 86 and $81 \%$ of them being urban population in 2002 and 2010, respectively (general urbanization rate in Russia is 73\%). The highest concentration of ethnic Tajiks (measured by the share of ethnic Tajiks in the regional population) is observed in the oil-extracting regions, Tyumen and Yakutia, followed by the industrially developed regions of Novosibirsk and Sverdlovsk. The capital cities occupy the sixth and seventh places. Roughly one-third of the Russian permanent population of Tajik ethnicity are citizens of Tajikistan. Notably, the share of ethnic Tajiks residing in Moscow has been declining, with $30 \%$ of the total number of ethnic Tajiks residing in Russia, living in Moscow in 2002, and $20 \%$ in 2010. The top five destinations made 50\% in 2002 and $42 \%$ in 2010. It is difficult to argue why this change happened. One explanation could be the extremely high cost of living in Moscow, especially housing prices that one incurs when settling with a family.

\section{Results and discussion}

\subsection{Location choice determinants}

The author starts with identifying regional characteristics that can explain migrants' location choices. The results presented in Table 4 comprise the maximum number of available observations and represent the stock of Tajik migrants in Russia throughout 3 years of the survey: 2007, 2009, and 2011.

Most of the variables included in the model are statistically significant and have predicted signs. Migrants go to regions with larger population size and density and higher wages. The co-ethnics concentration variable-share of ethnic Tajiks in the regional population-is also significant and is a strong predictor of location choice. Regional economy structure also affects migrants' decisions. Migrants are more attracted to regions with more people employed in industrial production, which indicates a stronger economy, and less attracted to regions with

8 Permanent population is defined as individuals who spent 12 months or more in the country's territory.

9 For the census of 2002 data, see Russian State Statistical Committee (2018a).

10 For the census of 2010 data, see Russian State Statistical Committee (2018b). 
Table 4 Conditional logistic regression of Tajik migrants' choice between Russian regions, (2007, 2009, and 2011 pooled sample)

\begin{tabular}{|c|c|c|c|c|}
\hline & (1) & (2) & (3) & (4) \\
\hline Unemployment rate, \% & $1.20^{\star \star \star}(0.08)$ & $1.28^{\star \star \star}(0.10)$ & $1.20^{\star \star \star}(0.08)$ & $1.14^{\star \star}(0.07)$ \\
\hline Change in unemployment rate (in pp.) & & $0.89^{\star}(0.06)$ & & \\
\hline Log of average wage (in 1,000 RuR) & $6.72^{\star \star \star}(3.14)$ & $6.98^{\star \star \star}(3.21)$ & $6.73^{\star \star \star}(3.15)$ & \\
\hline Change in average wage (in \%) & & & $1.00(0.02)$ & \\
\hline $\begin{array}{l}\text { Log of construction sector output } \\
\text { (1,000 RuR per } 1 \text { citizen) }\end{array}$ & & & & $1.12(0.24)$ \\
\hline $\begin{array}{l}\text { Change in construction sector output } \\
\text { (in \%) }\end{array}$ & & & & $1.43(0.44)$ \\
\hline Log of population size (in 1,000 people) & $2.86^{\star \star \star}(0.48)$ & $3.08^{\star \star \star}(0.52)$ & $2.86^{\star \star \star}(0.50)$ & $3.28^{\star \star \star}(0.58)$ \\
\hline $\begin{array}{l}\text { Population density (in } 1,000 \text { people } \\
\text { per } \mathrm{km}^{2} \text { ) }\end{array}$ & $2.38^{\star \star \star}(0.15)$ & $2.50^{\star \star \star}(0.17)$ & $2.38^{\star \star \star}(0.15)$ & $2.61^{\star \star \star}(0.16)$ \\
\hline $\begin{array}{l}\text { Migration quota (work permits } \\
\text { per } 1,000 \text { citizens) }\end{array}$ & $0.99(0.00)$ & $0.99(0.00)$ & $0.99(0.00)$ & $0.99^{\star \star}(0.00)$ \\
\hline Number of ethnic Tajiks per 1,000 citizens & $1.66^{\star \star \star}(0.17)$ & $1.73^{\star \star \star}(0.19)$ & $1.66^{\star \star \star}(0.17)$ & $1.77^{\star \star \star}(0.18)$ \\
\hline $\begin{array}{l}\text { Share of labor force employed in } \\
\text { manufacturing (in \%) }\end{array}$ & $1.12^{\star \star \star}(0.03)$ & $1.13^{\star \star \star}(0.03)$ & $1.12^{\star \star \star}(0.03)$ & $1.10^{\star \star \star}(0.02)$ \\
\hline $\begin{array}{l}\text { Share of labor force employed in utilities } \\
\text { personal and social services (in \%) }\end{array}$ & $0.79(0.12)$ & $0.73^{\star \star}(0.12)$ & $0.79(0.12)$ & $0.90(0.13)$ \\
\hline Share of labor force employed in mining & $0.98(0.03)$ & $0.99(0.03)$ & $0.98(0.03)$ & $1.02(0.03)$ \\
\hline Number of observations & 109,142 & 109,142 & 109,142 & 109,142 \\
\hline
\end{tabular}

Notes: Dependent variable - migration of individual $i$ to region $j$ in period $t$; controls for federal districts included; the values presented are the odds ratios; standard errors clustered in primary sampling units in parentheses.

${ }^{\star * *} p<0.01,{ }^{\star *} p<0.05,{ }^{*} p<0.1$.

more people employed in utilities and personal and social services. Probably, in the former regions, the local population is ready to take predominantly low-skilled jobs in the sector and therefore provides less job opportunities for migrants. Characteristics of economic dynamics have predicted signs, but change in the unemployment rate is significant only at the $10 \%$ level, and change in construction sector is not statistically significant.

Some of the factors do not have intuitive effects. Migrants go more probably to regions with higher unemployment. We cannot expect that a generally low unemployment across Russian regions will be an important factor for migrants choosing their destination. Also, higher unemployment might mark regions unattractive for internal migrants. Higher relative migration quotas associate with less probability to choose a region. Thus, the quota mechanism is not able to route migration streams. We are going to see whether this result is stable across the years, as the mechanism of quotas distribution was not the same.

Multicollinearity can be an issue in our data. In the pooled sample regressions where the number of potential destinations is larger, variance inflation factor (VIF) statistics do not exceed 4, which can be considered acceptable. Although in regressions for separate years, there is a strong multicollinearity because the number of alternatives becomes smaller. Therefore, results for separate years are not reported. 
Figure 1 Odds ratios of regional characteristics in 2007, 2009, and 2011. Note: 95\% confidence intervals depicted.

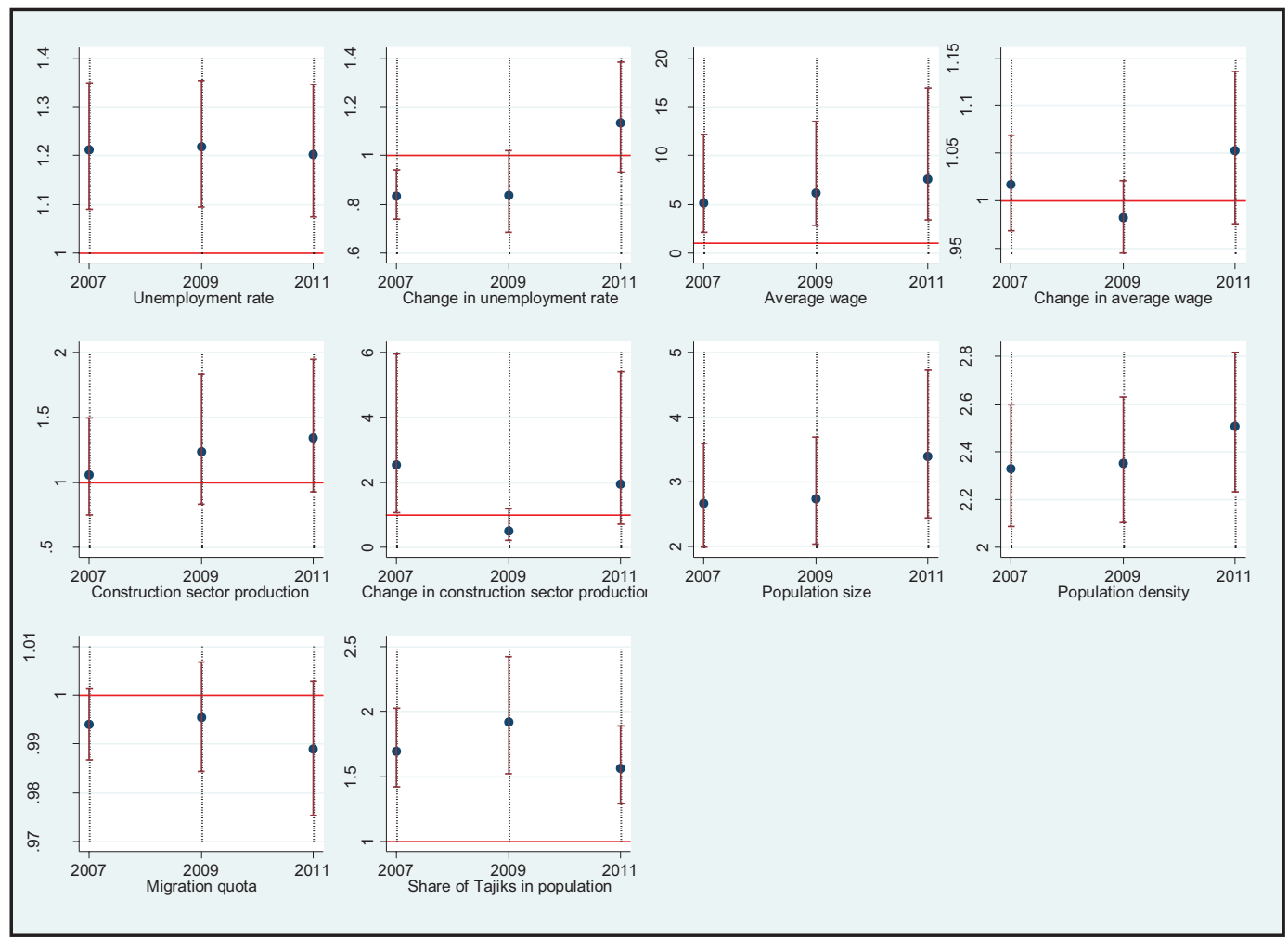

To show how the choice model evolves over time, the author adds interactions of the destination characteristics with the year of survey. Figure 1 depicts the odds ratios of the regional characteristics for the three survey years. Results are quite stable across the years. Still, we can see some dynamics in the effects of some variables. We see increasing importance of wages, population size, and density. These results reflect slowly rising concentration of migrants in Moscow. Interestingly, during the crisis year of 2009, migrants more consider the networks.

\subsection{Robustness of results}

Results do change when a different combination of controls is included. In particular, when population density is dropped from the regressors' list, unemployment is no more significant and the coefficient for average wages is rising considerably (Table A3 in Appendix). Still, we keep the specification with population density as a baseline model as the VIF statistics do not suggest that there is a multicollinearity problem.

A great concentration of migrants in Moscow creates a concern in our results. Dummy variable for Moscow that captures its time-invariant characteristics (e.g., historical network) is not statistically significant (Table A3 in Appendix). When Moscow is excluded from the sample, results do not change considerably (Table A3 in Appendix). The size and significance of average wage effect go down, so the level of income seems to be a more important factor for attracting migrants to the capital, but not to other regions. Noticeably, the effect of permanent Tajik population becomes larger. This shows that connections with co-ethnics are more important outside of Moscow. 
Another robustness check is using an alternative indicator of earnings-weighted sum of occupation-specific wages. ${ }^{11}$ It gives a close result to a basic specification (Table A3 in Appendix).

\subsection{Experience effects}

Now let us turn to analysis of the effect of previous experience. To do this, the author adds to regressions an interaction between regional characteristics and migration experience measured by the number of years a migrant was abroad as suggested by equation (5). The sample in this case includes only the years 2009 and 2011.

Figure 2 presents the predicted odds ratios of the regional variables depending on the migrant's experience abroad (regression coefficients can be found in Table A4 in Appendix). Results show that recent migrants are more sensitive to regional characteristics. An exception is the change in the construction sector, as experienced migrants might have better connections with employers and access to information about demand in case of new construction projects.

The observed changes in regional characteristics' effects with migration experience may reflect the importance of experience itself, the difference in decision-making between the cohorts or the change in migrant characteristics over time. To rule out the latter explanation,

Figure 2 Odds ratios of regional variables with number of years abroad. Note: 95\% confidence intervals depicted.

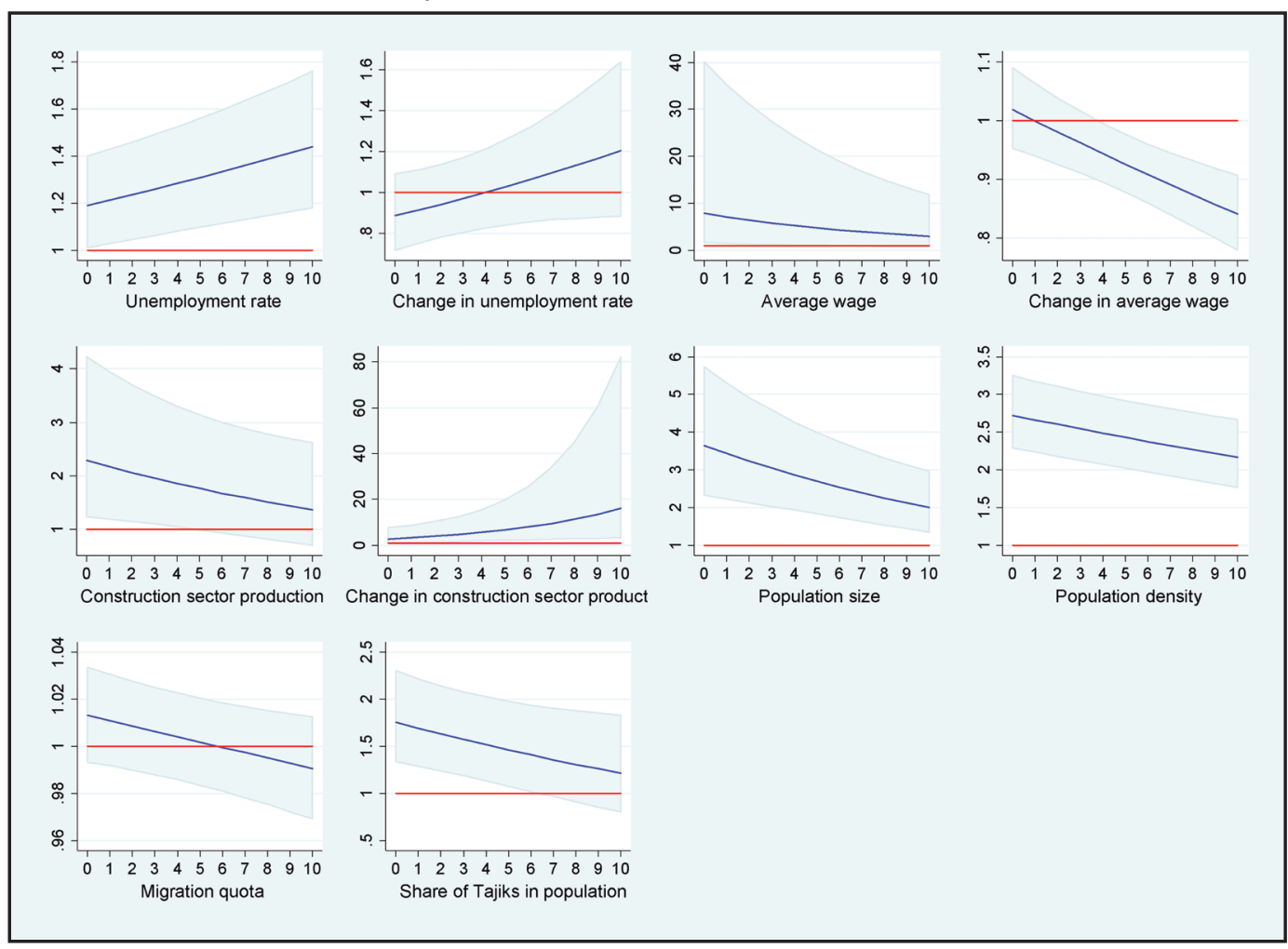

11 The indicator is calculated using migrants' occupations reported in the TLSS-THPS data and occupation-specific wages reported by Russian State Statistical Committee (Russian State Statistical Committee, 2018c). 
the author adds to the regressions the interactions with education, age, and gender (Table A5 in Appendix). The coefficients for the interactions between experience and regional characteristics do not change their significance or become more significant and only slightly change in size. Thus, the change in composition of migrant streams does not explain the observed patterns of experience effects. We also see that education and gender of migrants affect the importance of regional characteristics for the destination choice. Male migrants and migrants with professional education as opposed to those having secondary general and below are more sensitive to economic and demographic characteristics such as unemployment, wages, size of construction sector, and population size and density.

The other two hypotheses are both valid. Indeed, there exists path dependence in destination choice, so experienced migrants choose their destinations with less regard for current regional characteristics. On the other hand, earlier migrant cohorts could be less oriented toward the regional labor market characteristics as well as the organized migration network. Instead, they could rely more on their personal connections which are usually more randomly distributed throughout the country. Later cohorts rely more heavily on the organized network that emerges in regions with a strong economic position.

\section{Conclusion}

In this article, the author investigates the determinants of labor migrants' location choices within the receiving country by exploring the case of Tajik labor migrants in Russia. An emphasis is made on how previous migration experience affects the determinants of migrant choices.

The author finds that both the concentration of permanently settled co-ethnics and regional economic characteristics determine labor migrants' choices. The author did not find that the quota policy had a stable result on migrants' placements. Results show that economic dynamics had a weak effect on defining migrant locations, but the measures that were used could not capture the world economic crisis well enough.

Migration experience is an important factor affecting factors of location decisions. Such an experience expands migrant networks, both among other migrants and the local population, provides better knowledge of local labor market and formal and informal rules. Thus, migration experience is expected to improve employment probability and reduce costs of migration. At the same time, migration experience makes migrants less sensitive to current economic situation in the regions. The author finds that effects of the majority of factors decline with migration experience; therefore, current regional characteristics are much less relevant for the experienced migrants. These results suggest existing inertia in the geography of migrant concentration: once a location has been chosen, a migrant keeps on going there even if the situation has been changing. On the other hand, new streams of migrants are able to quickly decide to change the geographical location of settlement.

Temporary migrants are often considered to be the most mobile and ready to relocate part of the workforce. Our results show that previous migration experience affects current choices and reduces the responsiveness of migration streams to the changing economic environment in the receiving regions. In the absence of direct estimates of the sensitivity of migrant flows, these results may help predict how flows of migrants to Russia will react to macroeconomic shocks. 


\section{List of abbreviations}

CIS, Commonwealth of Independent States

GDP, Gross Domestic Product

ISCO, International Standard Classification of Occupations

PPP, Purchasing Power Parity

THPS, Tajikistan Household Panel Survey

TLSS, Tajikistan Living Standard Survey

VIF, Variance Inflation Factor

\section{Declarations}

\section{Availability of data and materials}

The datasets analyzed during the current study are available in the World Bank's microdata repository, http:// microdata.worldbank.org/index.php/catalog/72 and http://microdata.worldbank.org/index.php/catalog/73 and in the Leibniz Institute's for East and Southeast European Studies repository, http://www.lambda. ios-regensburg.de/doi/thps_2011.html

The dataset of Russian regional statistics compiled by the author from the Rosstat open sources, generated during the current study, is available from the author on reasonable request.

\section{Competing interests}

The author declares that he has observed these principles.

\section{Funding}

The article was prepared within the framework of the HSE University Basic Research Program and funded by the Russian Academic Excellence Project '5-100'.

\section{Author contributions}

All the work in this paper was performed by EC. She read and approved the final manuscript.

\section{Acknowledgments}

I am greatly thankful to Michael Lokshin for academic guidance and to Vladimir Gimpelson and Olga Lazareva for helpful comments and suggestions.

\section{References}

Bartel, A. P. (1989): Where do the New US Immigrants Live? Journal of Labor Economics 7(4), 371-391.

Bauer T.; G. S. Epstein; I. N. Gang (2005): Enclaves, Language, and the Location Choice of Migrants. Journal of Population Economics 18(4), 649-662.

Bauer, T.; G. S. Epstein; I. N. Gang (2007): The Influence of Stocks and Flows on Migrants' Location Choices, in: Polachek, S. W.; O. Bargain (eds.) Aspects of Worker Well-Being (Research in Labor Economics, Volume 26), Bingley: Emerald Group Publishing Limited, 199-229.

Bauer, T.; G. S. Epstein; I. N. Gang (2009): Measuring Ethnic Linkages Among Migrants. International Journal of Manpower 30(1/2), 56-69.

Beine, M.; F. Docquier; Ç. Özden (2015): Dissecting Network Externalities in International Migration. Journal of Demographic Economics 81(4), 379-408.

Beine, M., S. Salomone (2013): Network Effects in International Migration: Education Versus Gender. The Scandinavian Journal of Economics 115(2), 354-380.

Borjas, G. J. (2006): Native Internal Migration and the Labor Market Impact of Immigration. Journal of Human Resources 41(2), 221-258.

Chiswick, B. R.; P. W. Miller (2004): Where Immigrants Settle in the United States. Journal of Comparative Policy Analysis: Research and Practice 6(2), 185-197.

Chiswick, Barry. R.; Paul W. Miller (2005): Do Enclaves Matter in Immigrant Adjustment? City \& Community 4(1): 5-35.

Choudinovskikh, O.; M. Denissenko (2013): Migration Between CIS Countries: Trends and Policy, in: Series Search Working Paper, WP3/06, Universitat de Barcelona. http://www.ub.edu/searchproject/wp-content/ uploads/2013/02/WP_3_6.pdf. Accessed 26 February 2019.

Cushing, B. (2007): Conditional logit, IIA, and Alternatives for Estimating Models of Interstate Migration.

Dahlberg, M.; M. Eklöf (2003): Relaxing the IIAAssumption in Locational Choice Models: A Comparison Between Conditional Logit, Mixed Logit, and Multinomial Probit Models. Nationalekonomiska institutionen. 
Damm, A. P. (2009): Ethnic Enclaves and Immigrant Labor Market Outcomes: Quasi-Experimental Evidence. Journal of Labor Economics 27(2), 281-314.

Danzer, A. M.; B. Dietz (2018): Migrants' Well-Being During the Global Financial Crisis: Economic and Social Predictors. Journal of Comparative Economics 46(3), 770-787.

Danzer, A.; O. Ivaschenko (2010): Migration Patterns in a Remittances Dependent Economy: Evidence from Tajikistan during the Global Financial Crisis. Migration Letters 7(2), 190-202.

Davis, B.; G. Stecklov; P. Winters (2002): Domestic and International Migration from Rural Mexico: Disaggregating the Effects of Network Structure and Composition. Population Studies 56(3), 291-309.

Denisenko, M.; E. Chernina (2017): The Migration of Labor and Migrant Incomes in Russia. Problems of Economic Transition 59(11-12), 886-908.

Edin, P. A.; P. Fredriksson; O. Åslund (2004): Settlement Policies and the Economic Success of Immigrants. Journal of Population Economics 17(1), 133-155.

Jaeger, D. A. (2000): Local Labor Markets, Admission Categories, and Immigrant Location Choice. Williamsburg, VA: College of William and Mary.

Jaeger, D. A. (2007): Green Cards and the Location Choices of Immigrants in the United States, 1971-2000, in Chiswick, B. R. (ed.) Immigration (Research in Labor Economics, Vol. 27). Bingley: Emerald Group Publishing Limited, 131-183.

Kaushal, N.; R. Kaestner (2010): Geographic Dispersion and Internal Migration of Immigrants. Frontiers of Economics and Globalization 8, 137-173.

Kerr, S. P.; W. R. Kerr (2011): Economic Impacts of Immigration: A Survey. Finnish Economic Papers. Finnish Economic Association 24(1), 1-32.

Kröger, A.; K. Meier (2011): Employment and the Financial Crisis: Evidence from Tajikistan, in: Proceedings of the German Development Economics Conference, 2011 50, Verein für Socialpolitik, Research Committee Development Economics.

Kumo, K. (2012): Tajik labour migrants and their remittances: Is Tajik migration pro-poor? Post-Communist Economies, 24(1), 87-109.

Longhi, S.; P., Nijkamp; J. Poot (2008): Meta-Analysis of Empirical Evidence on the Labour Market Impact of Immigration. Region et Developpement 27, 161-191.

Marat, E. (2009): Shrinking Remittances Increase Labor Migration from Central Asia. Central Asia-Caucasus Institute Analyst 11, 7-9.

Ministry of Health and Social Development of Russia (2007): Order No 185, March 22, 2007.

Ministry of Health and Social Development of Russia (2008a): Order No 73n, February 18, 2008.

Ministry of Health and Social Development of Russia (2008b): Order No 777n, December 26, 2008.

Ministry of Health and Social Development of Russia (2009): Order No 1008n, December 22, 2009.

Ministry of Health and Social Development of Russia (2010): Order No 1080n, December 8, 2010.

Mocetti, S.; C. Porello (2010): How does Immigration Affect Native Internal Mobility? New Evidence from Italy. Regional Science and Urban Economics 40(6), 427-439.

Olimova, S.; I. Bosc (2003): Labour Migration from Tajikistan. Dushanbe: International Organization for Migration. http://iom.tj/pubs/Labor_Migration_Eng.pdf. Accessed 26 February 2019.

Pena, A. A. (2009): Locational Choices of the Legal and Illegal: The Case of Mexican Agricultural Workers in the US. International Migration Review 43(4), 850-880.

Russian State Statistical Committee (2011): Trud i Zanyatost v Rossii. 2011: stat.sb. [Work and employment in Russia. 2011: Statistic Book]. Moscow, 637. Available at: http://old.gks.ru/wps/wcm/connect/rosstat_ main/rosstat/ru/statistics/publications/catalog/doc_1139916801766. Accessed 13 November 2019.

Russian State Statistical Committee (2018a): Data. Retrieved December 15, 2018, from Russian State Statistical Committee. http://www.perepis2002.ru/index.html?id=11.

Russian State Statistical Committee (2018b): Data. Russian State Statistical Committee. http://www.gks.ru/ free_doc/new_site/perepis2010/croc/perepis_itogi1612.htm. Accessed 15 December 2018.

Russian State Statistical Committee (2018c): Data. Russian State Statistical Committee, Regions of Russia. Socio-Economic Indicators. http://old.gks.ru/wps/wcm/connect/rosstat_main/rosstat/ru/statistics/ publications/catalog/doc_1138623506156. Accessed 13 November 2019.

Russian State Statistical Committee (2018d): Data. Russian State Statistical Committee, Regions of Russia. Main Characteristics of the Constituent Entities of the Russian Federation. http://old.gks.ru/wps/wcm/ connect/rosstat_main/rosstat/ru/statistics/publications/catalog/doc_1138625359016. Accessed 13 November 2019.

Russian State Statistical Committee (2019): Data. https://gks.ru/accounts. Accessed 13 November 2019.

Schneider, L., A. Kubis (2009): Are there Gender-Specific Preferences for Location Factors? A Grouped Conditional Logit-Model of Interregional Migration Flows in Germany (No. 5/2009): IWH Discussion Papers. 
Scott, D. M.; P. A. Coomes; A. I. Izyumov (2005): The Location Choice of Employment-based Immigrants among US Metro Areas. Journal of Regional Science 45(1), 113-145.

Shemyakina, O. (2011a): The Effect of Armed Conflict on Accumulation of Schooling: Results from Tajikistan. Journal of Development Economics, 95(2), 186-200.

Shemyakina, O. N. (2011b): The Labor Market, Education and Armed Conflict in Tajikistan, in: Policy Research Working Paper, No 5738, The World Bank.

State Statistical Agency of Tajikistan (2007): Tajikistan Living Standards Survey (TLSS) 2007. Ref. TJK_2007_ TLSS_v01_M. Dataset downloaded from http://microdata.worldbank.org/index.php/catalog/72.

State Statistical Agency of Tajikistan (2009): Tajikistan Living Standards Survey (TLSS) 2009. Ref. TJK_2009_ TLSS_V01_M. Dataset downloaded from http://microdata.worldbank.org/index.php/catalog/72.

Tajikistan Household Panel Survey (2011): Institute for East and Southeast European Studies, Regensburg. http://doi.org/10.15457/thps_2011.

Word Bank (2007): Migration and Development Brief 3. Washington, DC: World Bank.

Word Bank (2008): Migration and Development Brief 8. Washington, DC: World Bank.

Word Bank (2009a): Migration and Development Brief 10. Washington, DC: World Bank.

World Bank (2009b): Russian Economic Report(English). Russia Economic Report; No. 20. Washington, DC:World Bank. http://documents.worldbank.org/curated/en/678311468306534253/Russian-economic-report.

Word Bank (2018): Data. World Development Indicators. http://databank.worldbank.org. Accessed 26 November 2018.

Zavodny, M. (1999): Determinants of Recent Immigrants' Locational Choices. International Migration Review 33(4), 1014-1030. 


\section{Appendix}

Table A1 Migrants' distribution across Russian regions, \%

\begin{tabular}{|c|c|c|c|c|}
\hline & Total & 2007 & 2009 & 2011 \\
\hline Moscow & 60.23 & 57.79 & 60.75 & 63.31 \\
\hline St Petersburg & 6.54 & 6.7 & 6.18 & 6.6 \\
\hline Sverdlovskaya & 5.82 & 6.39 & 5.91 & 4.92 \\
\hline Tyumenskaya & 2.19 & 1.56 & 3.23 & 2.24 \\
\hline Irkutskaya obl & 1.85 & 1.4 & 1.08 & 3.13 \\
\hline Samarskaya & 1.85 & 2.18 & 1.75 & 1.45 \\
\hline Chelyabinskaya & 1.75 & 1.71 & 1.34 & 2.13 \\
\hline Novosibirskaya obl & 1.23 & 1.32 & 1.48 & 0.89 \\
\hline Krasnodarsky kray & 1.16 & 1.01 & 0.4 & 2.01 \\
\hline Volgogradskaya obl & 0.92 & 0.86 & 1.08 & 0.89 \\
\hline Kemerovskaya & 0.79 & 0.62 & 0.54 & 1.23 \\
\hline Permsky kray & 0.68 & 0.7 & 0.27 & 1.01 \\
\hline Rostovskaya obl & 0.65 & 0.55 & 0.54 & 0.89 \\
\hline Tatarstan & 0.48 & 0.78 & 0.13 & 0.34 \\
\hline Orenburgskaya obl & 0.48 & 0.47 & 0.67 & 0.34 \\
\hline Ryazanskaya obl & 0.44 & 0.39 & 0.13 & 0.78 \\
\hline Moscow region & 0.41 & 0.23 & 1.08 & 0.11 \\
\hline Tverskaya & 0.41 & 0.16 & 0.81 & 0.45 \\
\hline Kaluzhskaya & 0.34 & 0.16 & 0.67 & 0.34 \\
\hline Khabarovskaya & 0.34 & 0.39 & 0.4 & 0.22 \\
\hline Saratovskaya & 0.31 & 0.47 & 0.4 & 0 \\
\hline Yaroslavsky krai & 0.31 & 0.23 & 0.54 & 0.22 \\
\hline Bashkortostan & 0.21 & 0 & 0.4 & 0.34 \\
\hline Altayski kray & 0.17 & 0.39 & 0 & 0 \\
\hline Omskaya obl & 0.17 & 0.23 & 0.27 & 0 \\
\hline Penzenskaya & 0.17 & 0 & 0.54 & 0.11 \\
\hline Smolenskaya & 0.17 & 0 & 0.4 & 0.22 \\
\hline Astrakhanskaya obl & 0.14 & 0.23 & 0.13 & 0 \\
\hline Voronezskaya & 0.14 & 0 & 0.27 & 0.22 \\
\hline Arkhangelsk & 0.1 & 0.08 & 0.27 & 0 \\
\hline Lipetskaya & 0.1 & 0.08 & 0.27 & 0 \\
\hline Nizhni-Novgorod & 0.1 & 0.08 & 0.13 & 0.11 \\
\hline Tomskaya & 0.1 & 0.08 & 0.13 & 0.11 \\
\hline Tulskaya & 0.1 & 0.16 & 0 & 0.11 \\
\hline Khakassia & 0.03 & 0.08 & 0 & 0 \\
\hline Amurskaya obl & 0.03 & 0 & 0.13 & 0 \\
\hline Kurganskaya & 0.03 & 0.08 & 0 & 0 \\
\hline Tambovskaya & 0.03 & 0 & 0.13 & 0 \\
\hline
\end{tabular}


Table A1 (Continued)

\begin{tabular}{lcccc}
\hline & Total & $\mathbf{2 0 0 7}$ & $\mathbf{2 0 0 9}$ & $\mathbf{2 0 1 1}$ \\
\hline Ulyanovskaya & 0.03 & 0.08 & 0 & 0 \\
Yakutia & 0.03 & 0 & 0 & 0.11 \\
Bryanskaya obl & 0.03 & 0 & 0 & 0.11 \\
Other & 8.9 & 12.38 & 7.53 & 5.03 \\
\hline
\end{tabular}

Table A2 Summary statistics for explanatory variables

\begin{tabular}{lcccc}
\hline Variable & Mean & $\begin{array}{c}\text { St. } \\
\text { dev. }\end{array}$ & Min & Max \\
\hline Population size (in 1,000 people) & 2,542 & 1,967 & 531 & 11,091 \\
Population density (in 1,000 people per km ${ }^{2}$ ) & 0.2 & 0.8 & 0.0003 & 4.3 \\
Migration quota (work permits per 1,000 citizens) & 36.03 & 18.95 & 10 & 94.27 \\
Number of ethnic Tajiks per 1,000 citizens & 1.11 & 0.72 & 0.23 & 3.33 \\
Unemployment rate, \% & 6.61 & 2.23 & 1.6 & 12.4 \\
Average wage ${ }^{1}$ (in 1,000 RuR) & 15,403 & 5,066 & 9,850 & 35,582 \\
Construction sector output ${ }^{1}$ (in 1,000 RuR per 1 citizen) & 24.98 & 16.75 & 5.21 & 91.78 \\
Change in unemployment rate (in pp.) & -0.56 & 1.18 & -4.1 & 1.8 \\
Change in average wage (in \%) & 13.11 & 3.46 & 4.59 & 19.89 \\
Change in construction sector output (in \%) & 10 & 15 & -31 & 58 \\
Share of labor force employed in manufacturing (in \%) & 17.17 & 5.52 & 4.1 & 27.02 \\
Share of labor force employed in utilities personal and & 3.6 & 0.56 & 2.54 & 4.93 \\
social services (in \%) & & & & \\
Share of labor force employed in mining (in \%) & 1.65 & 2.77 & 0.02 & 12.32 \\
\hline Note: Inflated to 2010
\end{tabular}

Note: ${ }^{1}$ Inflated to 2010. 


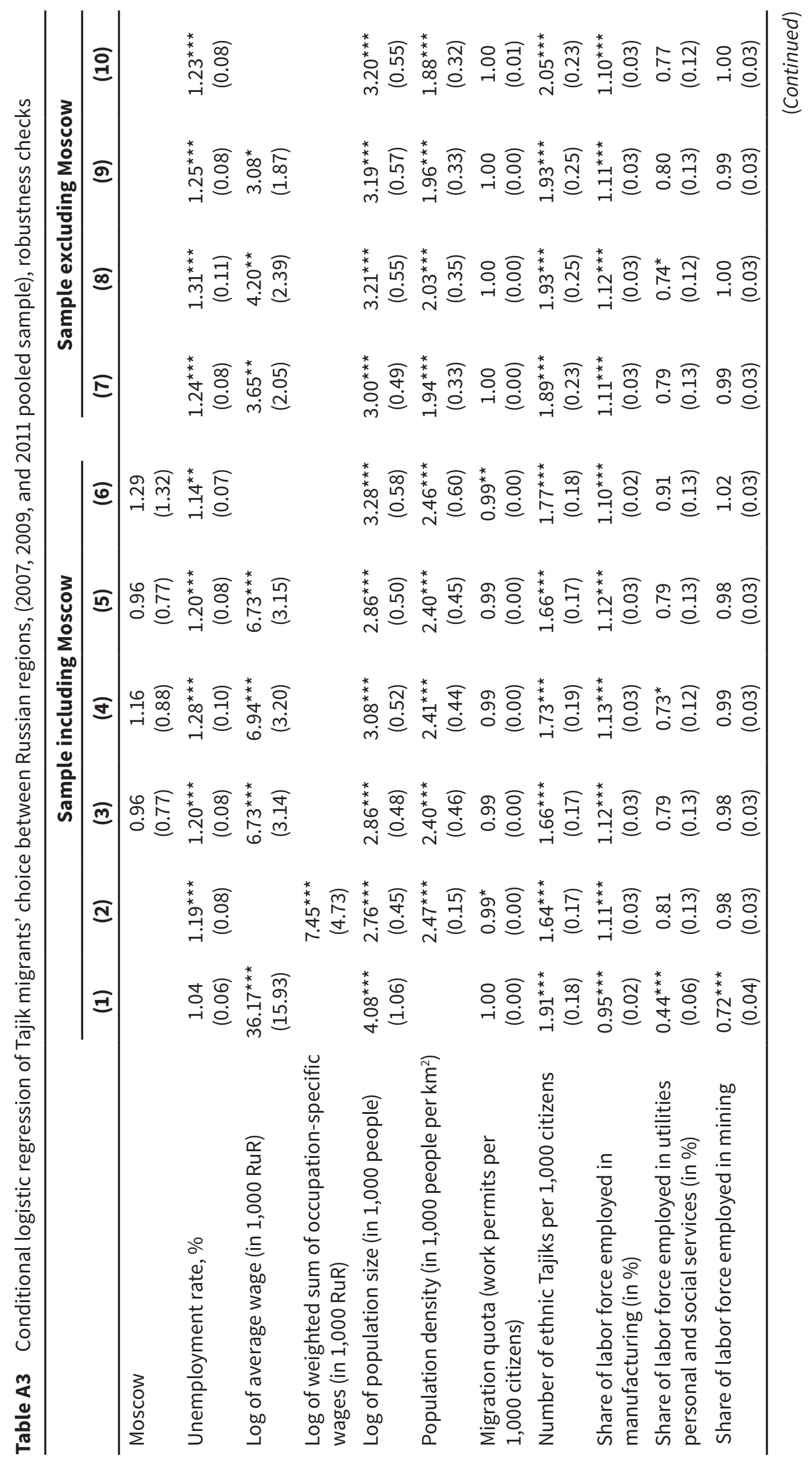




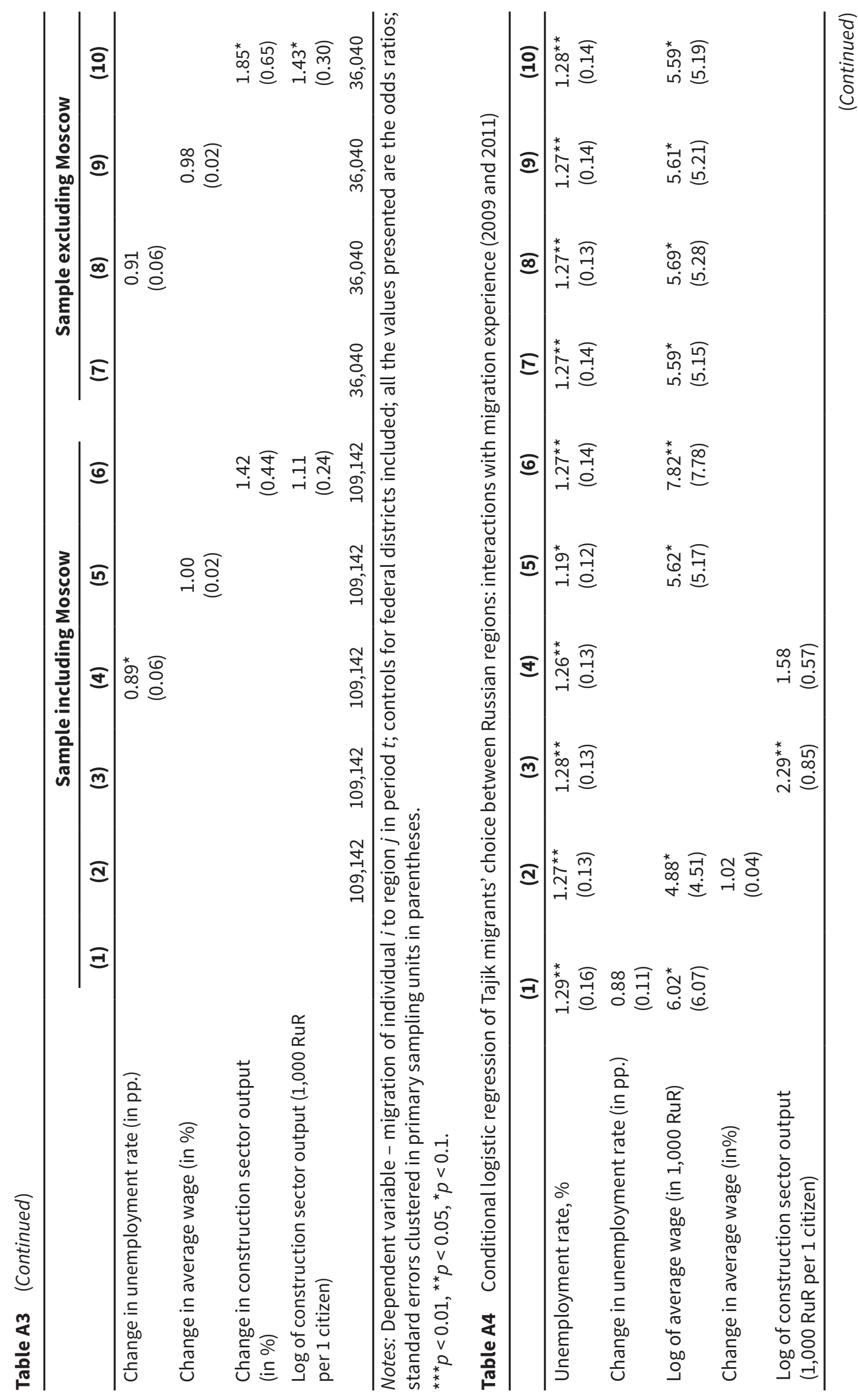




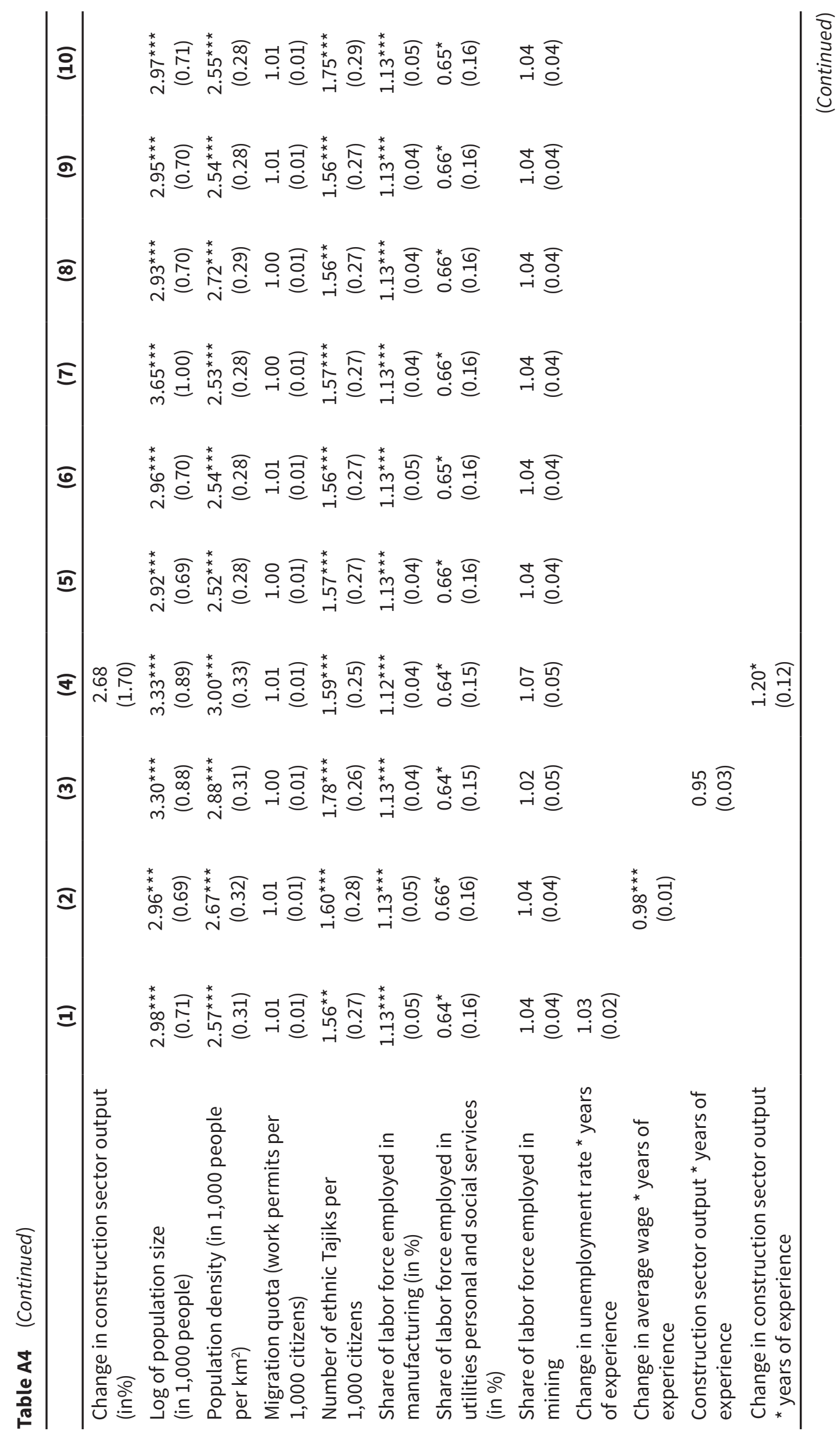




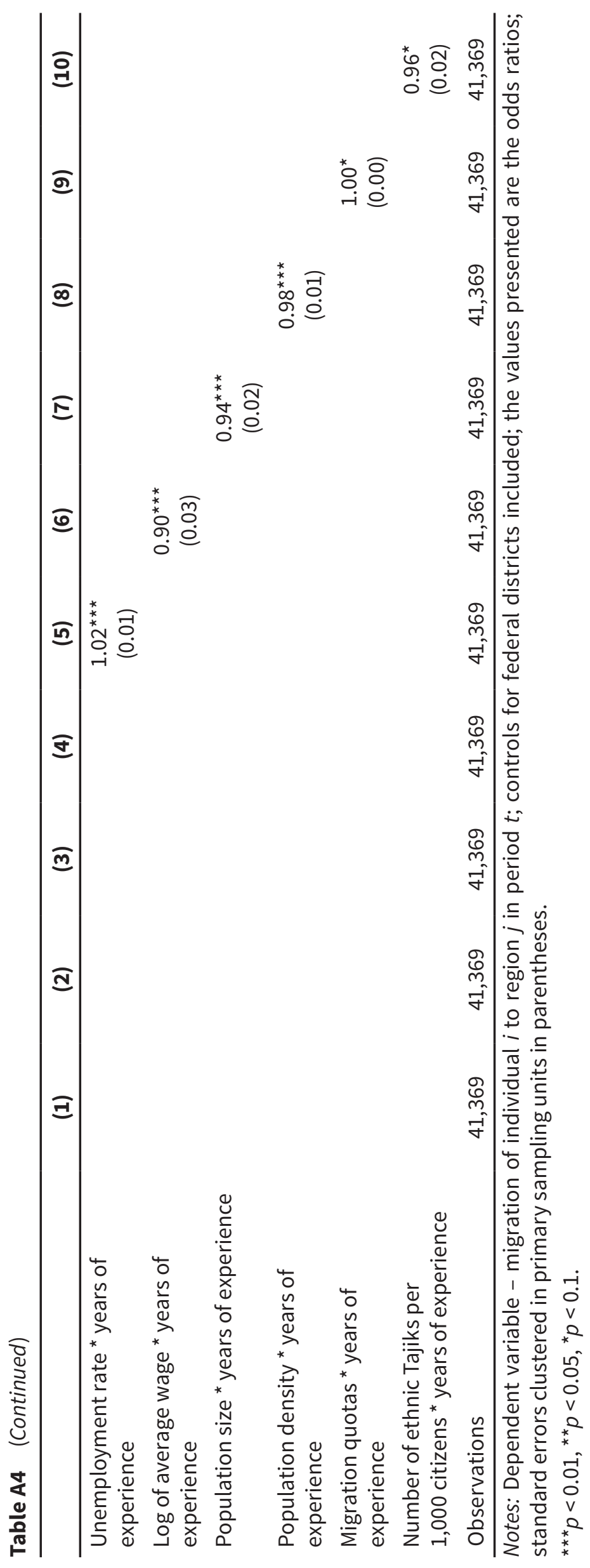




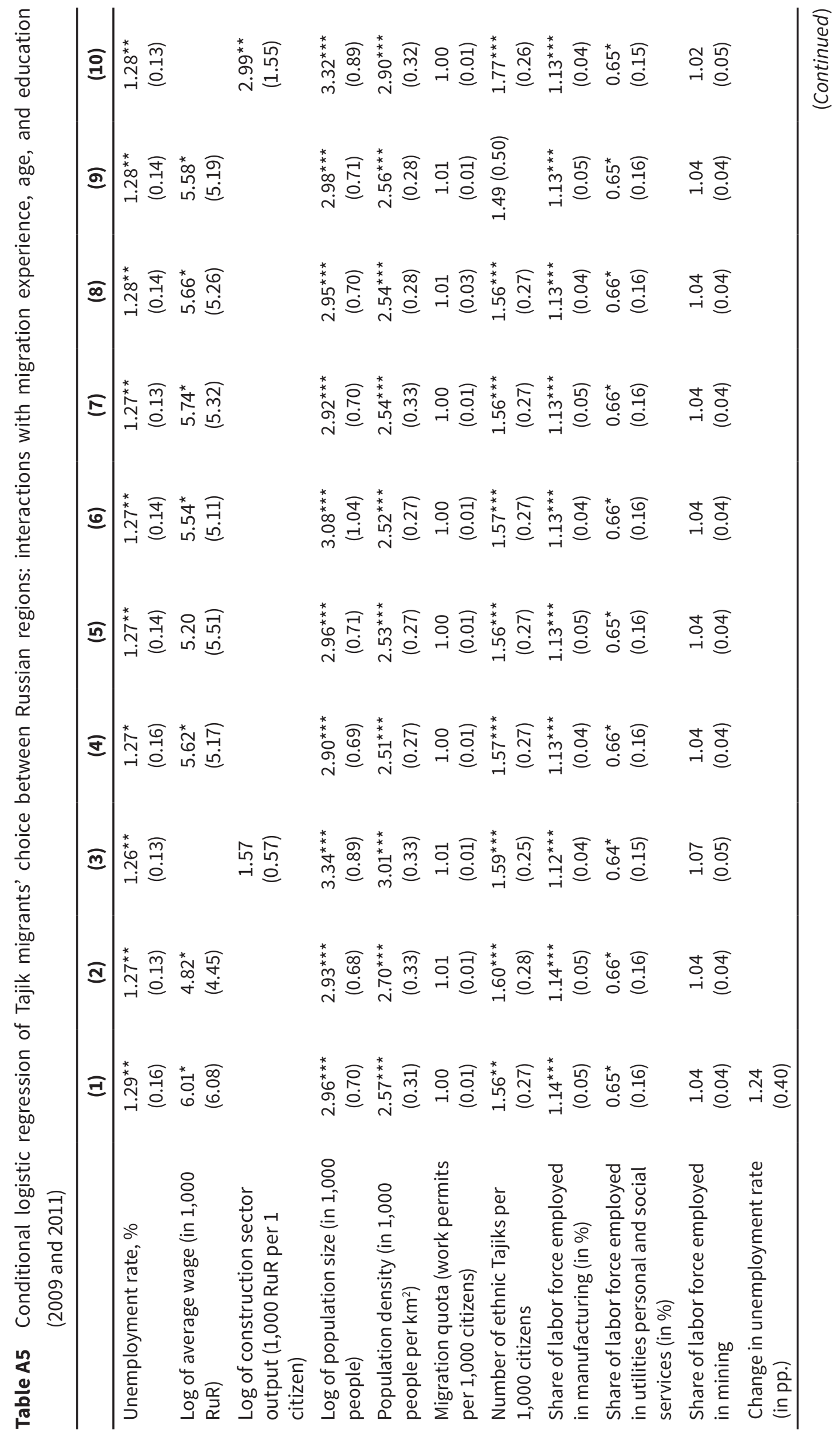




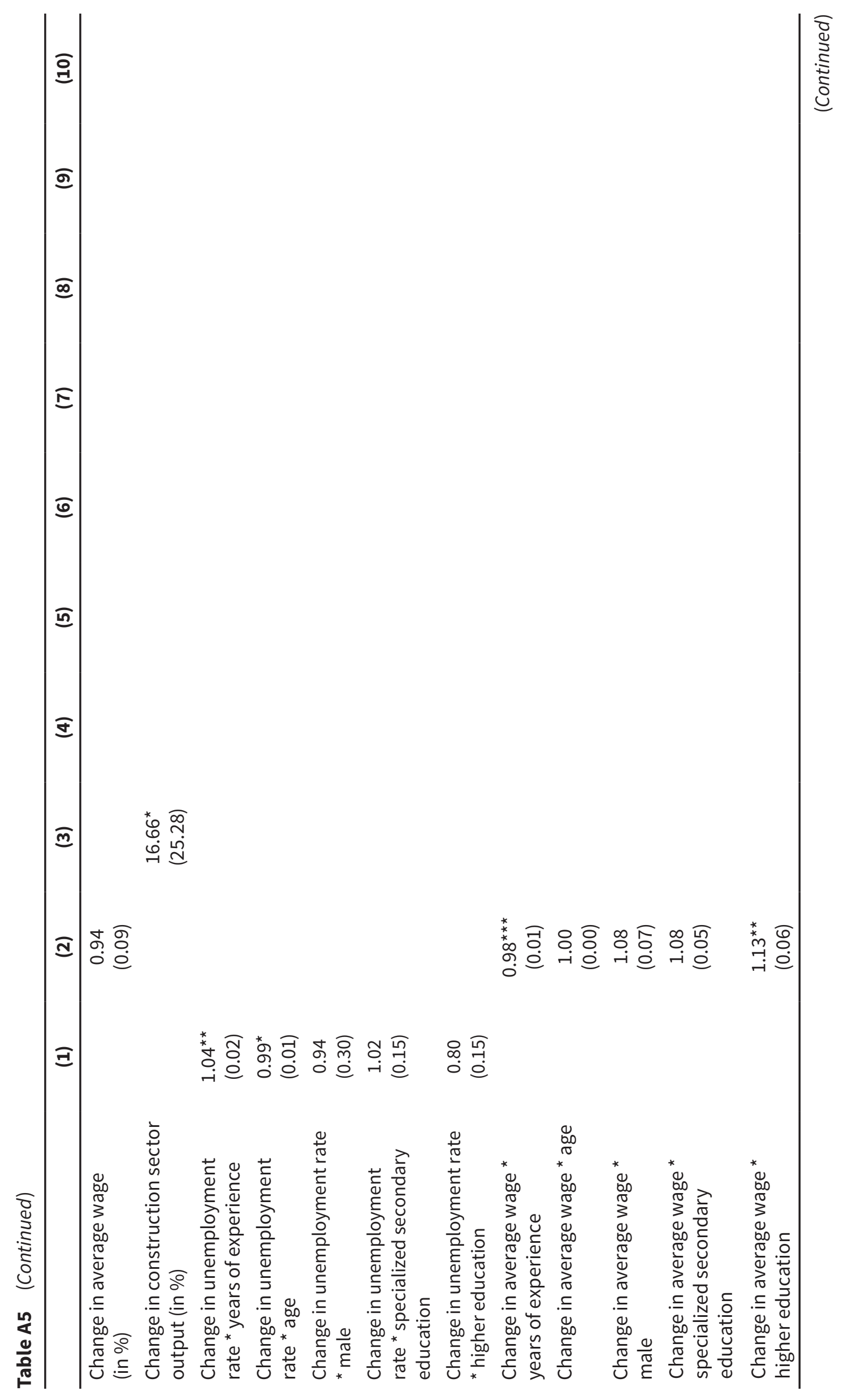




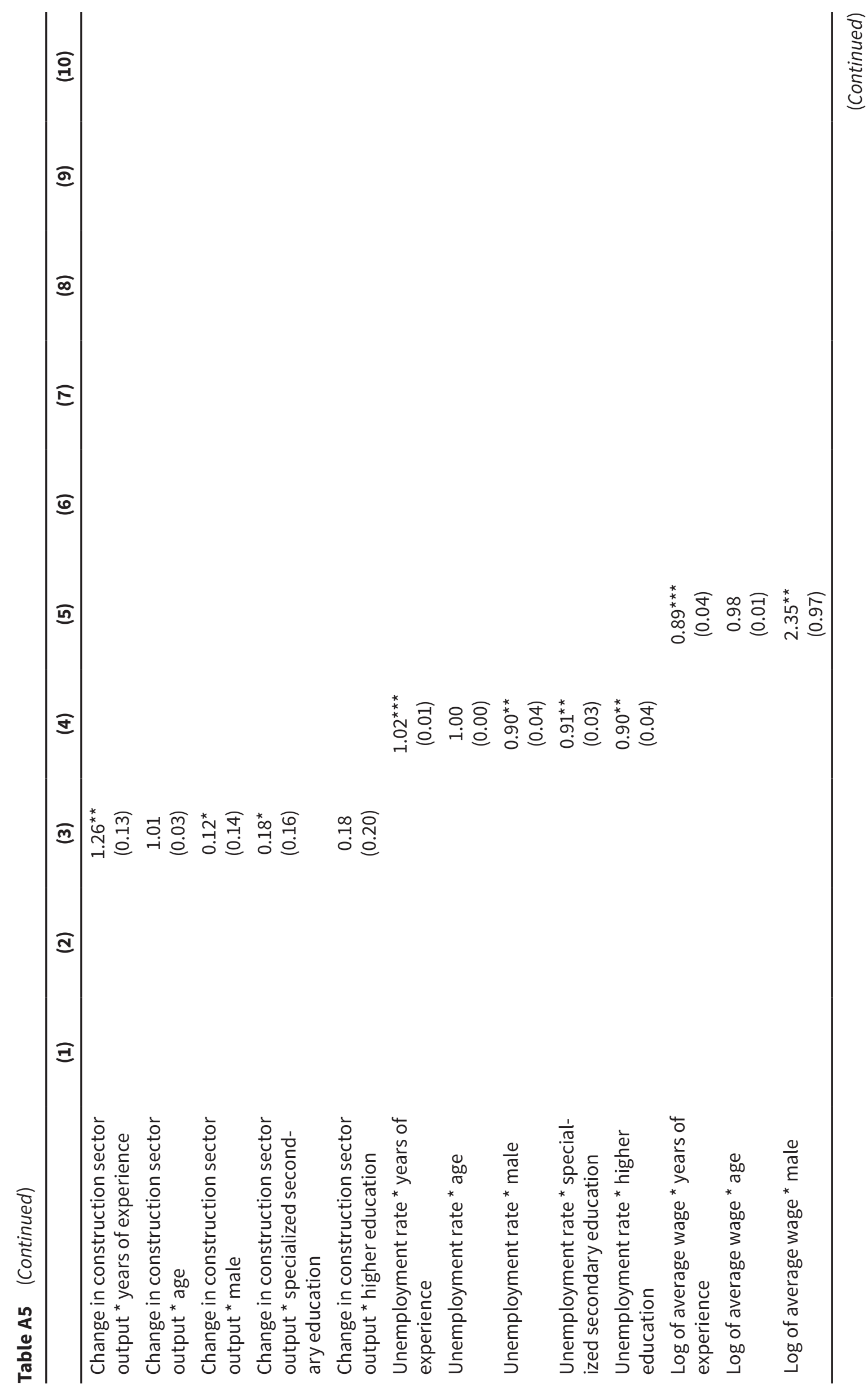




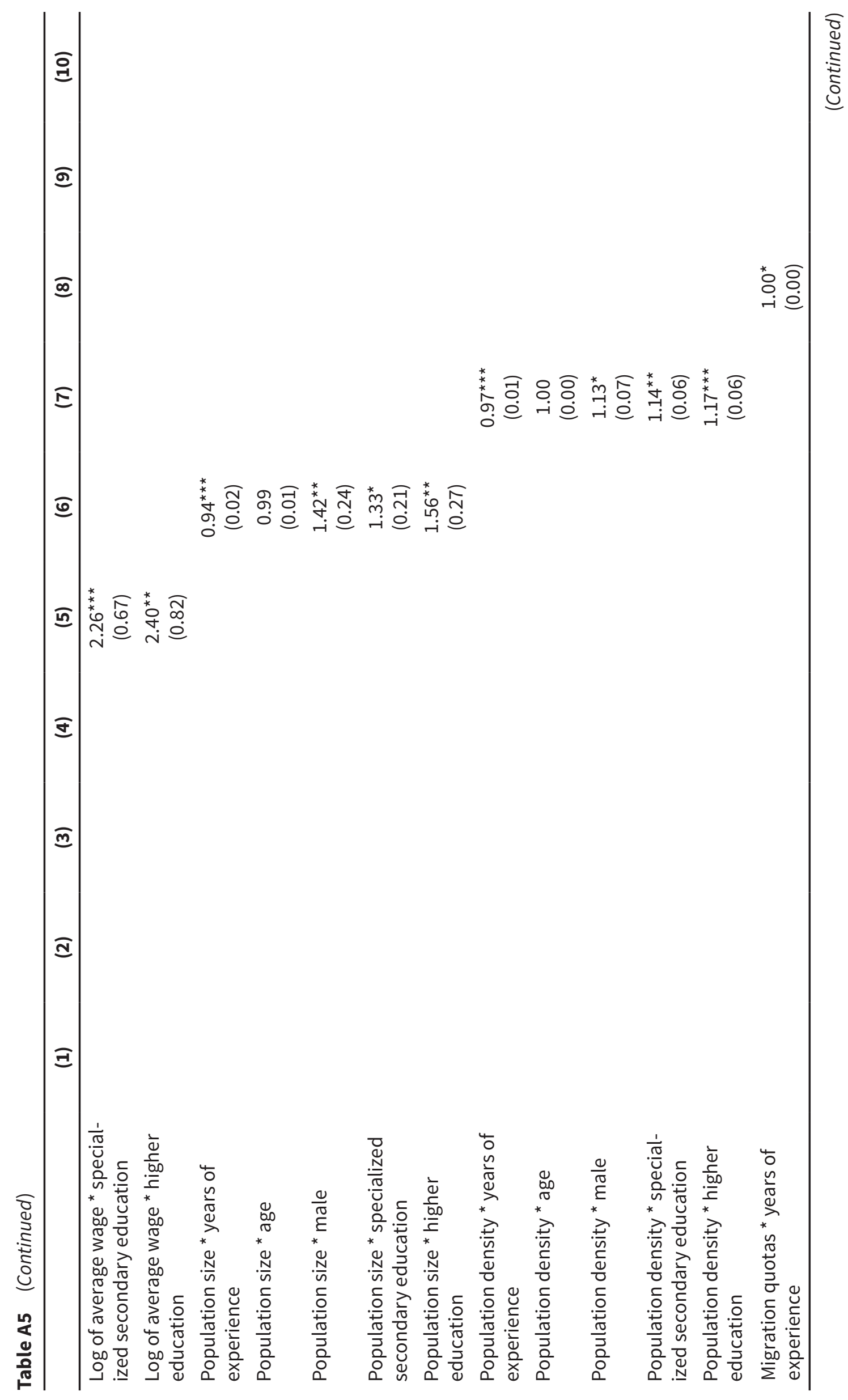




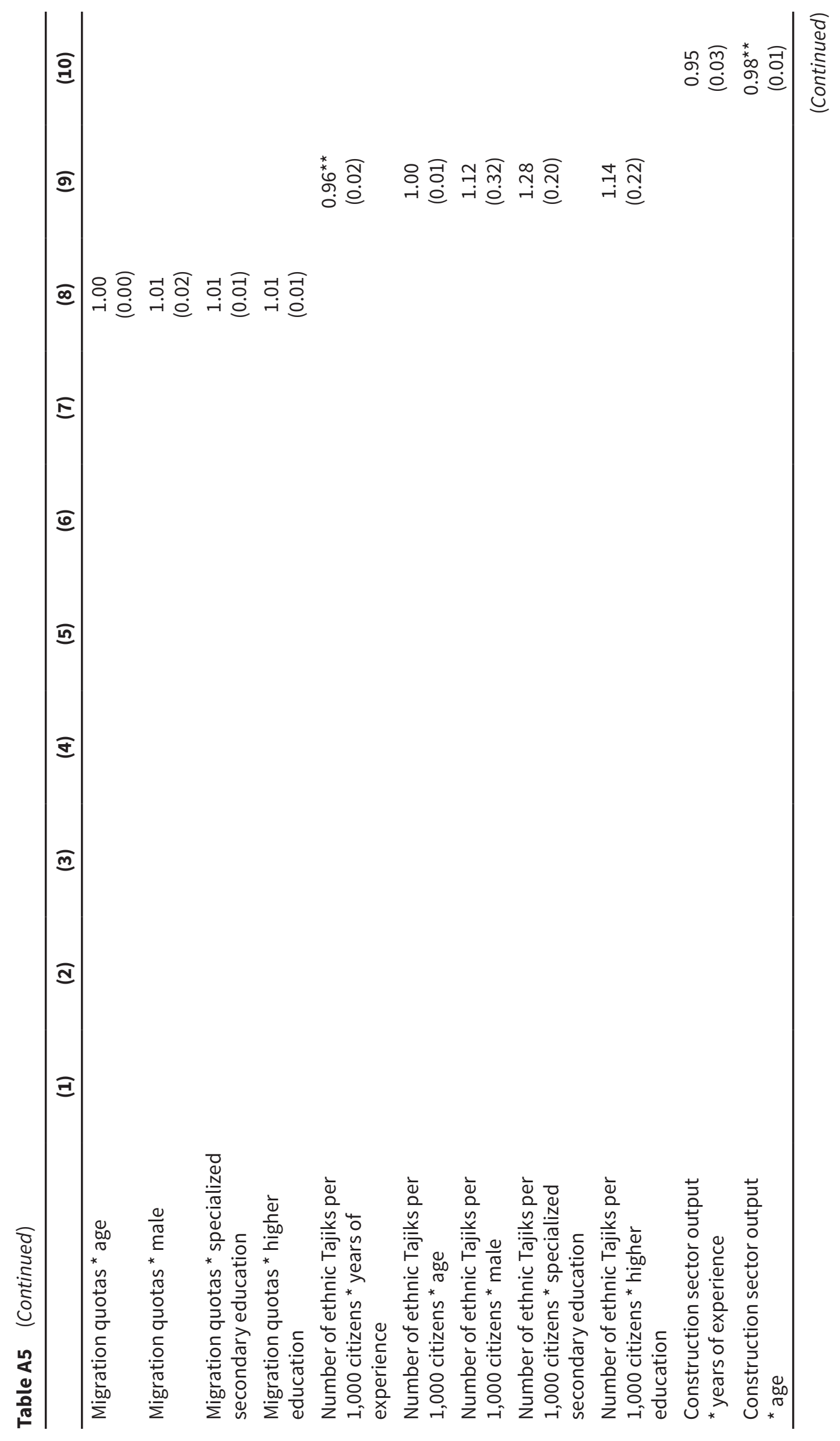




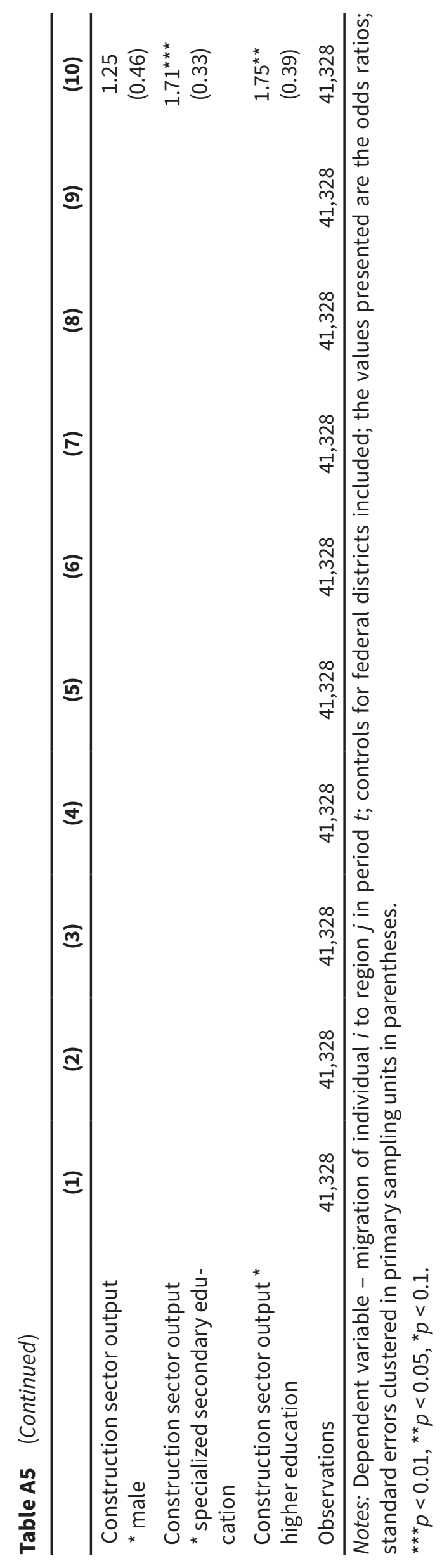

